\title{
1. Fiscal federalism in the twenty-first century
}

\author{
Richard Eccleston, Richard Krever and \\ Helen Smith
}

\subsection{INTRODUCTION}

This volume is concerned with the changing nature of fiscal federalism and federal governance in the twenty-first century. Case studies are used to understand the impact of existing federal structures and pressures and intervening and exacerbating factors - particularly the global financial crisis at the close of the first decade of the twenty-first century - on fiscal federalism. The studies are founded on a common theoretical and methodological foundation.

Federal systems are notoriously complex and varied (Treisman 2007). This, of course, means that no single trend or general hypothesis can fully explain contemporary trends in federal governance - trends, it will be seen, which head in very different directions in different jurisdictions. It is the case, however, that theoretically informed case study analysis represents the best way to understand how fiscal pressures and their political consequences have interacted with deeply institutionalized federal structures to shape distinctive patterns of federal governance. Theoretically informed narratives focused on emerging trends across a range of significant federal regimes can provide both empirical and theoretical insights into contemporary federalism.

Uncovering new insights into contemporary federalism is significant because of its broader implications for the practice of governance and democratic accountability. Leaving aside the normative debate as to whether federal governance and which of fiscal and political centralization or decentralization is desirable, it is important to understand whether prevailing political and economic forces in particular jurisdictions are driving centralization or decentralization and under what circumstances (Watts 2008; Beramendi 2007; Dardanelli et al. 2015). As was noted in the Introduction to this volume, it can be argued that the majority of the 
world's largest and most significant nations are federal in character. The book examines whether the broad trend toward federalization is likely to continue and under what circumstances.

\subsection{VARIETIES OF FEDERALISM}

The form and function of federal systems matter. The structure of federal systems not only influences levels of democratic participation and the extent of devolved decision-making, but it also influences the capacity of national political systems to respond to external shocks and emerging political challenges as well as the likely trajectory of political reform (Banting 2005; Beland and Myles 2012). Despite the importance of federal structures for contemporary political practice, there are significant challenges and debates both in terms of what constitutes a federal system as well as the development of an accepted typology of the distinctive varieties of federal systems. As with most key social-scientific concepts, definitions of what constitutes a federal system are contested. Clearly a central element of a federal system of government is the existence of a political order in which two or more levels of government share a degree of political sovereignty and authority (Hueglin and Fenna 2015, p.4). However, consensus tends to break down among federalism scholars when asked whether power sharing needs to be constitutionally entrenched and protected. For example, in the late 1980s, Elazar (1987) noted the growing number of what he described as federal orders where regional governments lack formal constitutional rights yet have practical de jure sovereignty relative to the national administration. This approach has been subject to criticism by scholars who argue that subordinate governments must have constitutionally entrenched autonomy vis-à-vis central governments to be defined as federations (Hueglin and Fenna 2006, p. 32). To be sure, constitutional recognition is important and has substantive implications, including facilitating decentralization (Galligan 2006). At the same time, however, it is important that a study of federalism examines the relationships between central governments and regional administrations outside a formal constitutional framework if the reality on the ground is a de facto division between levels of governance of responsibilities and financial resources, whatever the constitutional framework may be. Federal systems are highly diverse, both in terms of constitutional design and the practice of intergovernmental relations (Riker 1964). Notably, a pragmatic interpretation of federalism is accepted in other areas of analysis. For example, the Republic of South Africa (see Chapter 13) is formally defined as a unitary state with a multilevel system of governance, yet is recognized by 
intergovernmental organizations, such as the Forum of Federations, as having a federal character. ${ }^{1}$

Equally importantly, given the aim of understanding changing federal dynamics, it is important to consider cases where recent fiscal and political pressures have disrupted and are reshaping the relationship between regional and national governments, including examples such as the United Kingdom, Spain and China, where regional governments might not possess formal sovereignty but do enjoy significant (and growing) political independence. Indeed, in the UK and Spain this process of devolution and federalization may result in greater constitutional recognition of formerly subordinate governments. As Alfred Stepan argued in his influential essay on federalism and democracy (1999, p. 20), a narrow focus on federal systems based on the US model results in an incomplete and insufficiently broad definition of federalism to capture the range of forces or choices facing federalizing states.

For example, one significant dynamic identified in the case studies that follow is the emergence of 'holding-together' federalism where national political leaders come 'to the decision that the best way - indeed, the only way, to hold their countries together in a democracy would be to devolve [power]' (Stepan 1999, p. 22). Significantly, such processes are unlikely to result in a constitutionally entrenched, symmetrical federation but may lead to a formalized federacy where regions are granted specific concessions and a degree of fiscal independence and self-government. This emphasis on the practice of intergovernmental relations and the changing nature of fiscal and political power within federal regimes resonates with the wider notion of multilevel governance, with its emphasis on policy innovation and adaptation within intergovernmental systems despite relatively rigid and often sclerotic constitutional structures (Peters and Pierre 2004).

Even within the group of jurisdictions hosting constitutional federations there are numerous schemes for classifying the systems based on their history, constitutional design, culture, political practices and governance structures. While a comprehensive account of the literature on the varieties of federalism is not needed for this study, it is important to have an outline of some of the central themes that emerge from this scholarship given that the specific form of a federal system will influence both its propensity to adapt in the face of changing socio-economic circumstances and the likely contours of subsequent reforms.

The most established distinction in the federalism literature concerns constitutional design and the extent to which national and subordinate governments work in separate realms with reasonably clearly defined roles and responsibilities. At one end of the spectrum are traditional 'classical' or 'dual' federal systems where there is a reasonably clear demarcation 
between levels of government. The United States, Canada and Switzerland (Chapters 2, 3 and 7) have traditionally been presented as examples of classical federal systems in that states, provinces and cantons, respectively, enjoy significant constitutional powers and discretion relative to the national government (Hague and Harrop 2010, p. 276). At the other end of the spectrum are found examples of integrated federal systems where different levels of government enjoy sovereignty but engage in and have developed institutions to support high levels of coordination and joint decision-making. The German federation (Chapter 6) is widely regarded as being an exemplar of an integrated union.

The chapters that follow will touch on these themes, but it is important to note that in practice all systems of federal government feature elements of intergovernmental cooperation. For example, in the USA state governments still possess clear constitutional rights, but given the growth of the federal government (and associated programmes) over the course of the twentieth century even the USA features significant and growing intergovernmental administration (Kincaid 1990; Conlan 1998). Similarly, the level of intergovernmental coordination also varies across policy arenas within federal systems (Beland and Myles 2012), adding further to the challenge of classifying federal systems. However, given our interest in the impact of the financial crisis and its aftermath on federal systems our focus is on the extent to which the distribution of fiscal powers (centralization or decentralization) shapes federal dynamics in an era of growing fiscal pressure. These issues are discussed below and in subsequent chapters in greater detail.

The constitutional design of federal systems may have a significant impact on the practice of federal politics but there is increasing recognition that socio-historical factors will also shape the practice of intergovernmental relations and that interaction between societal pressures and the formal institutional features of a federal system will influence the dynamics of change. A host of historical and cultural variables are relevant here. For example, it could be significant to ask whether a federal system was formed through the voluntary union of pre-existing sovereigns such as in the USA or was the result of agreement between a colonial master and separate colonies as in the case of Canada and Australia. Alternatively, the federation could have developed as part of a new political settlement following conflict and/or decolonization as was the case in India, Germany and South Africa. Another scenario is where federalism is adopted to maintain the integrity of a pre-existing state threatened by a regional secessionist and independence movement. The hope in troubled unions such as Spain and the UK is that granting regional interests greater autonomy and self-determination within a federal structure will appease secessionist 
movements. Indeed, the enduring significance of the circumstances surrounding the genesis of federal systems for contemporary federal dynamics is captured nicely in Alfred Stepan's distinction between 'coming together' and 'holding together' federations (1999). One important finding of this book is that the exacerbation of fiscal and distributional grievances is driving significant change in 'holding together' federations in the form of providing greater fiscal transfers and increasing formal political rights to regions seeking greater independence as a strategy to preserve the political union.

In addition to the macro-historical circumstances that give rise to federal systems, a host of other societal variables shape federal dynamics. Perhaps the most significant factors are existing cultural and linguistic cleavages that in turn give rise to regional political representation and political parties. For example, there is a significant literature on the relationship between the existence of national party systems and the centralization of political and financial power in federal systems (Riker 1964; Filippov et al. 2004), while noting that the viability and influence of regional political parties is largely shaped by strong, regionally based linguistic or cultural cleavages (Chhibber and Kollman 2004). Reflecting this theme, federalism scholars have argued that the existence of strong linguistic or sectarian cleavages and an associated federal culture have provided a powerful and effective counterpoint to the strong trend to centralization in federal systems in recent years (Elazar 1987; Simeon and Radin 2010; Erk and Koning 2010). The different paths followed in Canada and Australia described in this volume may reflect this point.

A host of institutional features will also influence federal dynamics, including electoral systems and the extent of regional representation in the national legislature (usually the upper chamber) and various judicial safeguards, to name but a few (Bednar 2011; Broschek 2011, p. 545). Perhaps the most significant variables insofar as the analysis is concerned are the constitutional rules, legislative frameworks and associated practices concerning the allocation of taxing and spending powers and responsibilities across federal systems. There may, however, be but a weak connection at best between the notional formal allocation of fiscal rights and obligations and practice.

The significant literature from public economics on fiscal federalism tends to focus on questions of efficient institutional design and how to create political incentives to promote efficient and sustainable financial governance (for summaries see Anderson 2010; Shah 2007; Ahmad and Brosio 2006). Yet the reality is that intergovernmental financial relations are political compromises forged in constitutional settlements and shaped by subsequent political and economic developments. As a consequence the 
practice of fiscal federalism is both varied and evolving, with few federal jurisdictions conforming to identifiable ideal types. To the extent that general patterns can be observed, the trend (but with exceptions) to fiscal centralization over the second half of the twentieth century stands out (Oates 1972) as increased economic integration and interdependence has enhanced the case for tax harmonization and the centralization of revenue raising, phenomena often occurring without any formal constitutional amendments. At the same time, there has been a countervailing tendency towards the decentralization and devolution in relation to policy and budgeting decisions, especially in developing countries (Ahmad and Brosio 2006, p. 13; Blöchliger 2013). The consequence of these potentially contradictory forces on federal systems has been a general rise in vertical transfers between national and subnational governments to enable regional governments to fund programmes using national revenue streams. But here, too, a wide range of models have been applied, from systems of formal revenue sharing to increasing reliance on both project-specific 'tied' grants, which can limit the political autonomy of subnational governments, and on general-purpose block grants that provide for wide discretion.

The governance of systems of joint funding is also critical. Where decision-making about aims and design of jointly funded programmes is genuinely shared then the federal ideal can be preserved, yet where national governments use their superior fiscal capacity to pursue their own political interests at the expense of regional administrations then a form of 'coercive federalism' will result, with far-reaching accountability and governance problems (Kincaid 2010; Eccleston and Warren 2015). The final debate associated with increasing intergovernmental transfers concerns the merits of equalization regimes designed to redistribute resources from wealthy constituent units to those poorer jurisdictions in a federation.

While it is important to be cognizant of these broad trends in intergovernmental relations, as noted above, both federal systems generally and systems of intergovernmental financial relations in particular can be characterized more by their diversity than their conformity to readily identifiable ideal types. For this reason each of the 12 case studies contained in this volume provides a brief overview of the broad historical and political foundations of their federal systems, as well as more detailed analysis of their respective intergovernmental financial systems and the domestic political debates about their effectiveness and the need for reform. What is clear, and will be examined in more detail in section 1.3 below, is that in recent times an external factor, the 2008 global financial crisis, has played a significant role in determining the design and practice of contemporary federalism. The ongoing fallout from the financial crisis raises a host of questions: will growing pressures on national budgets result in declining 
transfers to subnational units? Will regional variations in the impact of the crisis undermine equalization regimes in federal systems? How will these dynamics be influenced by the rise of regional independence and secessionist movements, which have become increasingly prominent in some of our case study countries?

These are important questions because, as Benz and Broschek have observed (2013b, p. 378), the most significant causes of change in federal systems are ' $[\mathrm{t}]$ he economic disparities between regions which affect intergovernmental politics and policy-making, structures of conflict in federalism and debates on institutional reform'. Ultimately, the answers to these complex and multidimensional questions must be built on a comprehensive political economy approach that is cognizant of how the trajectory of political development is shaped by the historical interaction of social and economic relations (Polyani [1944] 2001). As will be outlined in greater detail below, historical institutionalism in political science and sociology arguably provides the most relevant theoretical and methodological foundation from which to conduct a detailed and nuanced analysis of the evolution of federal systems in the early twenty-first century. The next section will provide a more detailed overview of the existing literature on change in federal systems, followed in section 1.4 with empirical data on the economic impact of the financial crisis on federal systems. The remainder of the chapter is then devoted to outlining and operationalizing the institutionalist framework that informs the detailed case studies presented in the subsequent chapters.

\subsection{EXPLAINING CHANGE IN FEDERAL SYSTEMS}

This volume documents and analyses broad trends in federal governance with a view to providing new insights into the future of federalism. Yet until relatively recently, and with notable exceptions (Livingston 1956; Riker 1964; Sawer 1969), there has been remarkably little systematic research on how and why federal systems evolve and change over time. Moreover, the literature that does exist has traditionally focused on the circumstances and processes that give rise to formal constitutional change (Broschek 2011; Benz and Broschek 2013a, p. 2).

The paucity of research on the causes and consequences of change in federal systems can be attributed to the strong normative commitment held by many federalism scholars to preserving federal structures and practices in order to promote political accountability, economic efficiency and other 'socially desirable ends' (Bednar 2011, p. 271). This literature reflects the Madisonian view so influential in the USA that 
in large republics splitting sovereignty between member units and the federal government would protect individuals from abuses by authorities at either level. ${ }^{2}$ The notion that embedding federal practices in constitutionally entrenched rules and institutions would shape political behaviour and promote the common good gained further prominence over the course of the twentieth century, leading researchers to focus on designing ideal federal systems and developing political strategies to secure their implementation. For example, the extremely influential literature on the Tiebout hypothesis (1956) in public economics argued that political and economic competition in federal systems enhances both accountability and efficiency while, using a similar logic, Oates' theory of decentralization (1972) argues that devolved decision-making lowers the cost and improves the quality of services.

While these and many related theories gave rise to a host of empirical studies and scholarly debates, in a sense they only highlight the paucity of research focused on the real-world process of change and adaptation in federal systems (Bednar 2011). Federalism scholarship may have focused on preserving ideal federal systems but the reality is that federations, like all political regimes, are in a state of constant flux and change. As Fenna (2014, p. 1) observes:

Federations are in some ways the embodiment of an illusion: an illusion of permanence amid a reality of flux. No sooner is the ink dry on the constitutional terms cementing a set of hard fought compromises than the new federal order begins its evolution.

Such insights into the dynamic nature of federal governance have given rise to an increasingly sophisticated literature on how to conceptualize and explain the changing nature of federal governance. ${ }^{3}$ Whereas 'statist' accounts highlight how the institutional features of federal systems are designed to preserve the status quo, resulting in political settlements that are highly path dependent in the absence of a crisis or other exogenous shocks (Pierson 1996), this belies the ongoing and often significant process of evolution and adaptation (Behnke and Benz 2009). As Benz and Broschek conclude in their recent study of federal dynamics (2013b, p. 379), the evidence suggests that "neither state-centred or society-centred theories of federalism suffice in order to comprehend the complexity and variability' across cases.

\subsubsection{New Institutionalism and Federalism Research}

There has long been recognition that federal settlements embody historical compromises and that these 'constitutional moments' represent critical 
junctures that define the subsequent trajectory of constitutional evolution (Ackerman 1998; Broschek 2011, p. 540). What is increasingly being recognized in revisionist society-centred accounts of federalism, however, is that federal systems continue to adapt long after their founding settlement. Change can be conceived in a variety of forms and has just as many causes. For example, Behnke and Benz (2009) make an important distinction between the informal evolution of federal systems and more formal constitutional reform, a distinction refined further by Fenna (2012), who argues that evolution or adaptation often precedes and precipitates more formal constitutional reform in federal systems. Similarly, Benz and Colino (2011) describe four distinctive types of change (reform, innovation, evolution and adjustment) yet retain the key distinction between formal/intentional change and more pragmatic forms of adjustment.

Implicit in such accounts is recognition that while constitutional settlements and associated institutional practices establish the 'rules of the game' in federal systems, societal pressures can, over time, drive change and transcend the self-reinforcing and path-dependent trajectory evident in many federal systems (Erk 2008; Colino 2010; Colino and del Pino 2014). Indeed, the existing federalism literature provides a number of insights into the potential causes of such change. For example, Simeon and Conway (2001) argue that informal processes of evolution or adaptation have always been pervasive in federal systems and usually occur through the reinterpretation and extension of shared authorities (Hollander and Patapan 2007). Similarly, Colino (2010; Chapter 8 this volume) highlights how constitutional change in Spain has long been a 'bottom up' affair driven by changing regional interests and demands.

Evidence of how federal systems are structured by constitutional settlements, yet - under certain conditions - are susceptible to change and reform as a consequence of new socio-economic circumstances, resonates with broader theoretical debates in institutional theory in political science and sociology. Historical institutionalism, with its emphasis on how historical sequencing, contingent choices and settlements shape the formation of interests and the subsequent trajectory of change, is an especially relevant approach (Broschek 2011; Benz and Broschek 2013b). Early research in this tradition had an explicitly historical/comparative focus and explained how national policy frameworks, once institutionalized, retained their distinctive character despite ever-growing economic and political integration over the course of the twentieth century (Steinmo 1993; Hall and Taylor 1996; Peters 1999). Subsequent contributions to the literature examined the processes of path dependency and increasing returns that explained this institutional stability until a regime is disrupted by a 'critical juncture' or transformational crisis (Pierson 2000). This research was persuasive in 
being able to explain both cross-national variations in institutional structures (including federal systems) and persistence of institutional orders long after their creation, but provided fewer insights into how institutions evolved during more normal times.

Historical institutionalism's limited capacity to explain change was outlined in an influential essay by Thelen and Steinmo (1992, p. 16) in the early 1990s that described this as a "critical inadequacy of institutional analysis' that 'has a tendency towards mechanical and static accounts that ... sometimes lapse inadvertently to institutional determinism' (see also Rothstein 1998; Bell 2005, p. 3). This 'problem of change' has subsequently become a focal point of theoretical discussion among institutionalist scholars (Campbell 2004, ch. 2; Pierson 2004, ch. 4; Kay 2006, ch. 2) and resonates with the parallel debates in the federalism literature regarding the relative significance of institutional and societal variables in explaining change.

A number of approaches have been advocated, all of which grapple with the broader structure-agency debate in the social sciences (Hay 2002). One response to this 'problem of change' is to recognize that institutions, including the rules and practices that constitute a federal system, are located in a wider structural context of economic and geopolitical relations, the socalled 'exogenous' context, which can change independently of a domestic institutional order and then guide shifts in that domestic regime. Perhaps the most influential account of these dynamics was Krasner's punctuated equilibrium model, which characterized institutional change as 'episodic and dramatic rather than continuous and incremental' (1984, p. 234). In terms of explaining contemporary trends in federal systems, the 2008 financial crisis and its fiscal repercussions could credibly be regarded as a critical juncture with the potential to disrupt federal regimes.

External shocks and crises clearly have the potential to precipitate institutional change, yet models that explain domestic change primarily as responses to these factors have been subject to two broad criticisms. First, while there is agreement that critical junctures can and do disrupt existing institutional regimes, such accounts have often been silent on the question of the scope and nature of subsequent change (Campbell 2004). Second, early punctuated equilibrium models largely ignored the possibility of more incremental endogenous processes that result in incremental change within institutional systems. While such processes are less dramatic than crisis-induced change, over the longer term these dynamics can have a significant impact. Increasingly there is recognition that these processes are not mutually exclusive, with scholars highlighting a composite process of 'punctuated evolution' that acknowledges the potential of both endogenous and exogenous causes of change (Hay 2002; Oliver and 
Pemberton 2004; Eccleston 2007). This revisionist literature focuses on the dialectic relationship between agency and institutions in an environment subject to broader structural forces and causes of change (Campbell 2004; Crouch 2005; Mahoney and Thelen 2010; Bell 2011). These developments in institutional theory resonate with cognate debates concerning the nature of change in federal systems outlined above that seek to explain how and when deeply institutionalized intergovernmental rules and practices are subject to adaptation and reform. Given these parallels, it is not surprising that contemporary research on federal dynamics draws heavily on new institutionalism (Broschek 2011; Benz and Broschek 2013a).

\subsubsection{Conceptualizing Change in Federal Systems}

The contribution from historical institutionalism that arguably provides the most significant insights into the specific processes resulting in change in federal systems is Mahoney and Thelen's (2010) conceptual framework for identifying specific endogenous mechanisms that lead to institutional change. This framework recognizes that pressures for change can manifest themselves through both explicit institutional change (reform) and implicit, or informal, adaptation. The specific process that gives rise to such change is largely determined by the extent to which there is institutional rigidity in a particular regime. These four variables (explicit/implicit change and high/ low degree of rigidity) give rise to four distinctive processes - layering, displacement, drift and conversion - (see Table 1.1) that have the potential to provide 'micro analysis to understand better the relationship between the governed population - individually and as collected into a federal culture and the institutions of government' (Bednar 2011, p. 281).

This typology can be used to identify potential processes that are likely to result in changes in federal governance over the longer term and thus has the potential to inform the empirical analysis in the case studies that

Table 1.1 Pathways to federal reform

\begin{tabular}{cll}
\hline & Explicit Change & Implicit Change \\
\hline $\begin{array}{c}\text { High degree } \\
\text { of rigidity }\end{array}$ & $\begin{array}{l}\text { Layering: introducing new } \\
\text { rules alongside or above } \\
\text { existing rules }\end{array}$ & $\begin{array}{l}\text { Drift: changed impact of existing } \\
\text { rules due to environment shifts }\end{array}$ \\
$\begin{array}{c}\text { Low degree } \\
\text { of rigidity } \\
\text { existing rules and introducing } \\
\text { new rules }\end{array}$ & $\begin{array}{l}\text { Conversion: changed enactment } \\
\text { of existing rules due to strategic } \\
\text { development }\end{array}$ \\
\hline
\end{tabular}

Source: Adapted from Broschek (2011). 
follow in this volume. However, it is also important to recognize the limitations of this approach. Historical institutionalism employs an inductive method that can be used to guide the interpretation of the complex and contingent political dynamics found in each of the case studies (see section 1.5). But while the approach identifies clear processes that may result in change, it says little about the connection between inputs and outputs. Conceptualizing change is useful but at the end of the day it is but one step along the path to the more ambitious goal of explaining the causes and direction of change so as to enhance an understanding of emerging trends in federal governance. In specific terms, it is necessary to understand the forces at work driving the process of change in federal systems down one path rather than another. As Fenna has argued (2014, p.4), the real test of any historical institutionalist explanation of change in federal systems is whether 'it can tell us anything interesting about different experiences in those federations that chose [a particular path]'.

Such questions highlight the need to analyse both the causes of change and the processes though which change is realized. Reflecting these themes, the following section examines the economic impact of the financial crisis of 2008-9 and its legacies on federal systems. Section 1.5 then draws on recent developments in institutional theory to discuss the role of political actors or 'agents' in shaping the trajectory of federalism reform.

\subsection{CRISIS FEDERALISM}

Contemporary institutional theory is concerned with the processes through which institutional structures mediate the relationship between domestic political actors and the broader political and economic context in which they are situated. This approach highlights the complex and potentially significant impacts that the financial crisis of 2008-9 and its varied economic impacts have on different federal orders. However, this analysis is also mindful of the distinctive impacts that domestic institutions, federal practices and domestic political actors can have on these processes. In short, the interaction between economic and political variables in shaping the future trajectory of federal relations must be acknowledged. This section describes the economic context in which federalism has been practised over the past decade. It begins by documenting the macroeconomic and fiscal impact of the crisis on the case study countries in this volume, before reviewing the relevant literature on the impact of the acute phase of the crisis on federal systems. Finally, the handful of recent studies that provide a preliminary assessment of the longer-term impact of the financial crisis on federal systems are considered. 


\subsubsection{The Economic Impact of the Crisis on Federations}

It is useful to distinguish between three discrete phases of the financial crisis and its aftermath when considering the consequences that impacted fiscal federalism. Specifically, the period between 2007 and 2009 can be characterized by the emergency response to the first phase crisis when economic growth, trade and investment slumped and unemployment rose sharply, especially in North America and Europe (Figures 1.1 and 1.2; Braun and Trein 2014, p. 804). The gravity of this economic challenge precipitated a large-scale, coordinated macroeconomic response including fiscal stimulus, corporate and financial bailouts and a drastic and unconventional easing in monetary policy.

Studies of the first phase of the crisis by federalism scholars have highlighted the key role of subnational governments in the immediate response. There is an ongoing debate in the literature on whether federalism promotes or hinders effective macroeconomic policy (Erk and Swenden 2010, p. 8) and rapid, coordinated policy responses (Wibbels 2000; Kincaid et al. 2010 , p. 6), with the crisis providing ammunition to both sides of the argument. As the case studies that follow will demonstrate, generally speaking the degree of cooperation between national and subnational governments was a crucial factor in the crisis recovery effort of many federations. Where subnational governments were willing to match the stimulus programmes of national administrations, crisis damage was often effectively mitigated (Ter-Minassian and Jiménez 2011, p.7); conversely, where regional governments instigated pro-cyclical spending cuts and tax increases contrary to national policy, the crisis deepened (Kincaid 2010, p.20; Rodden and Wibbels 2010). Subnational fiscal policy decisions were influenced and supported by other mechanisms and strategies developed by national governments, including relaxed fiscal rules (for example, reducing indebtedness targets, providing greater access to capital markets), low-cost loans, increased vertical transfers, and the devolution of tax revenues (Canuto and Liu 2010, p.4; Vartapetov 2011, p. 530; Ter-Minassian and Jiménez 2011 , p. 33). With some exceptions, overall the gravity of the acute phase of the crisis inspired unprecedented intergovernmental cooperation, raising hopes that this would result in a more enduring transformation.

Having implemented a variety of responses to the financial crisis and averted a more severe economic catastrophe, from 2009 onwards national policy-makers embarked on what can be termed the second phase of the crisis: a period of budget repair and fiscal consolidation and, in some cases, fiscal austerity (Figures 1.3 and 1.4). At this point, it became apparent just how varied the impact of the crisis had been. In purely economic terms, the data presented here demonstrate that some countries (such 

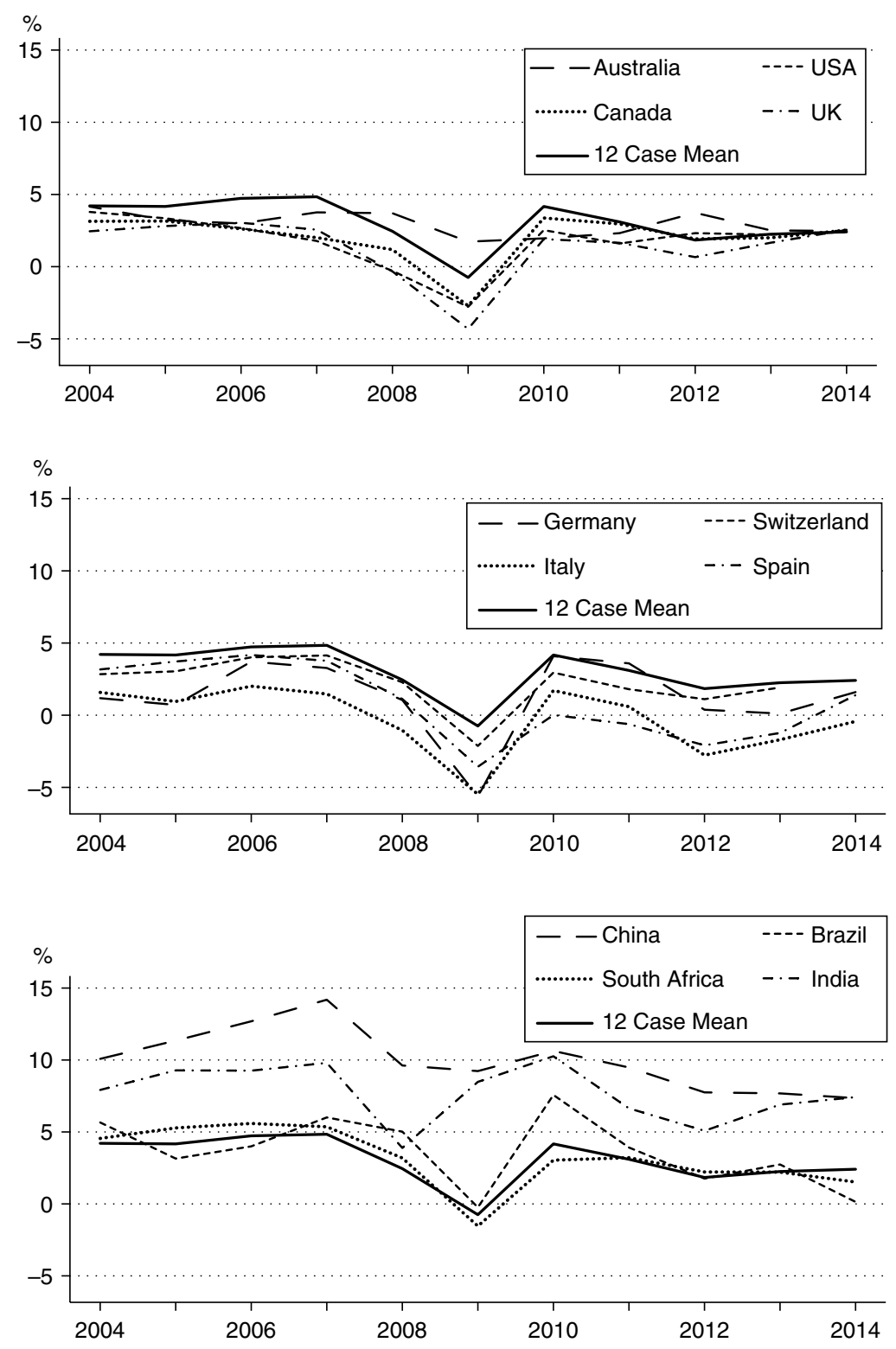

Source: The World Bank, World Development Indicators.

Figure 1.1 Change in GDP, 2004-14 

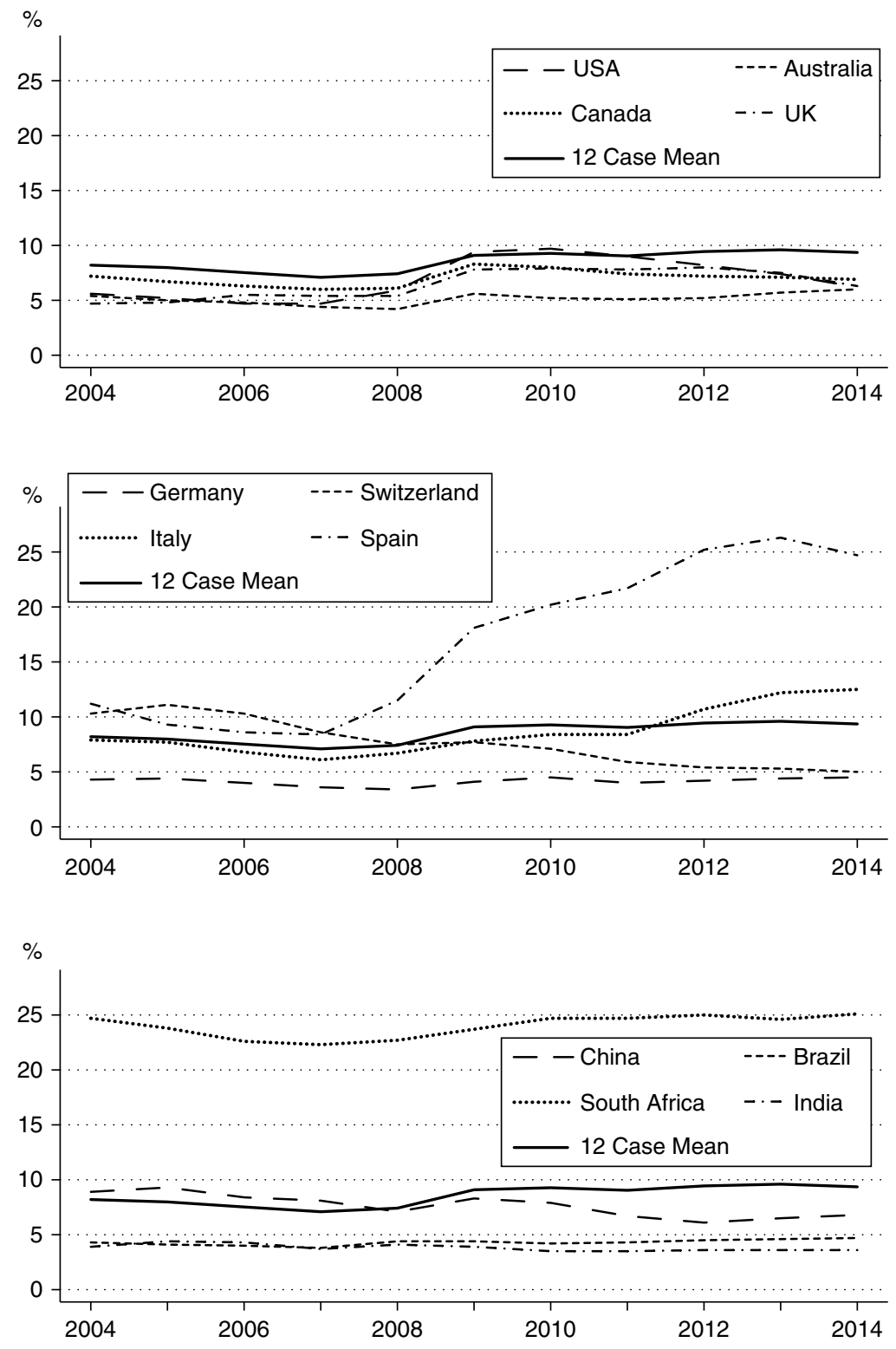

Source: The World Bank, World Development Indicators.

Figure 1.2 Change in unemployment, 2004-14 

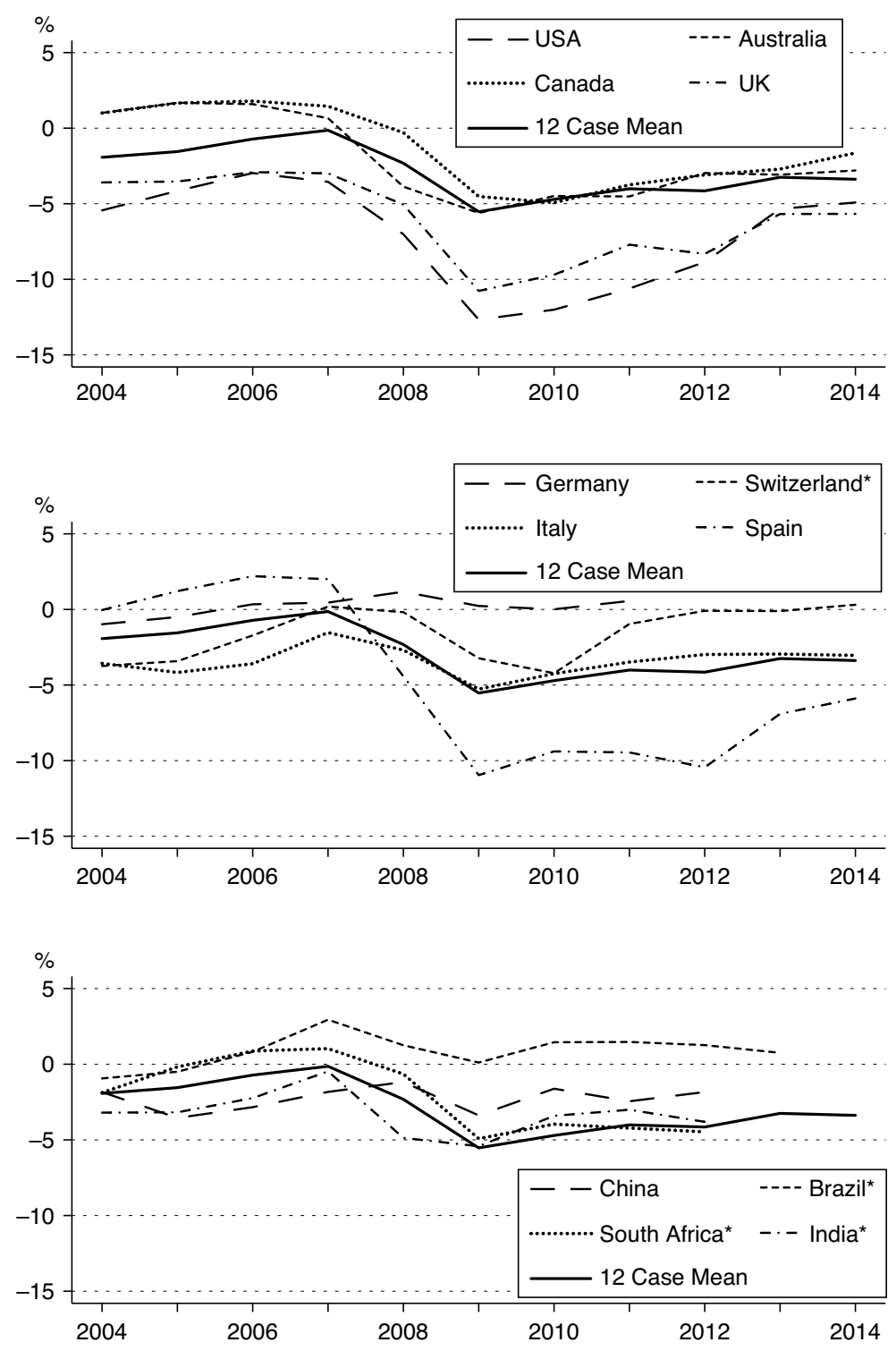

Note: * indicates from The World Bank, World Development Indicators. Cash surplus/ deficit ( $\%$ of GDP).

Source: OECD (2016), General government deficit (indicator).

Figure 1.3 Central government operating deficit, 2004-14 

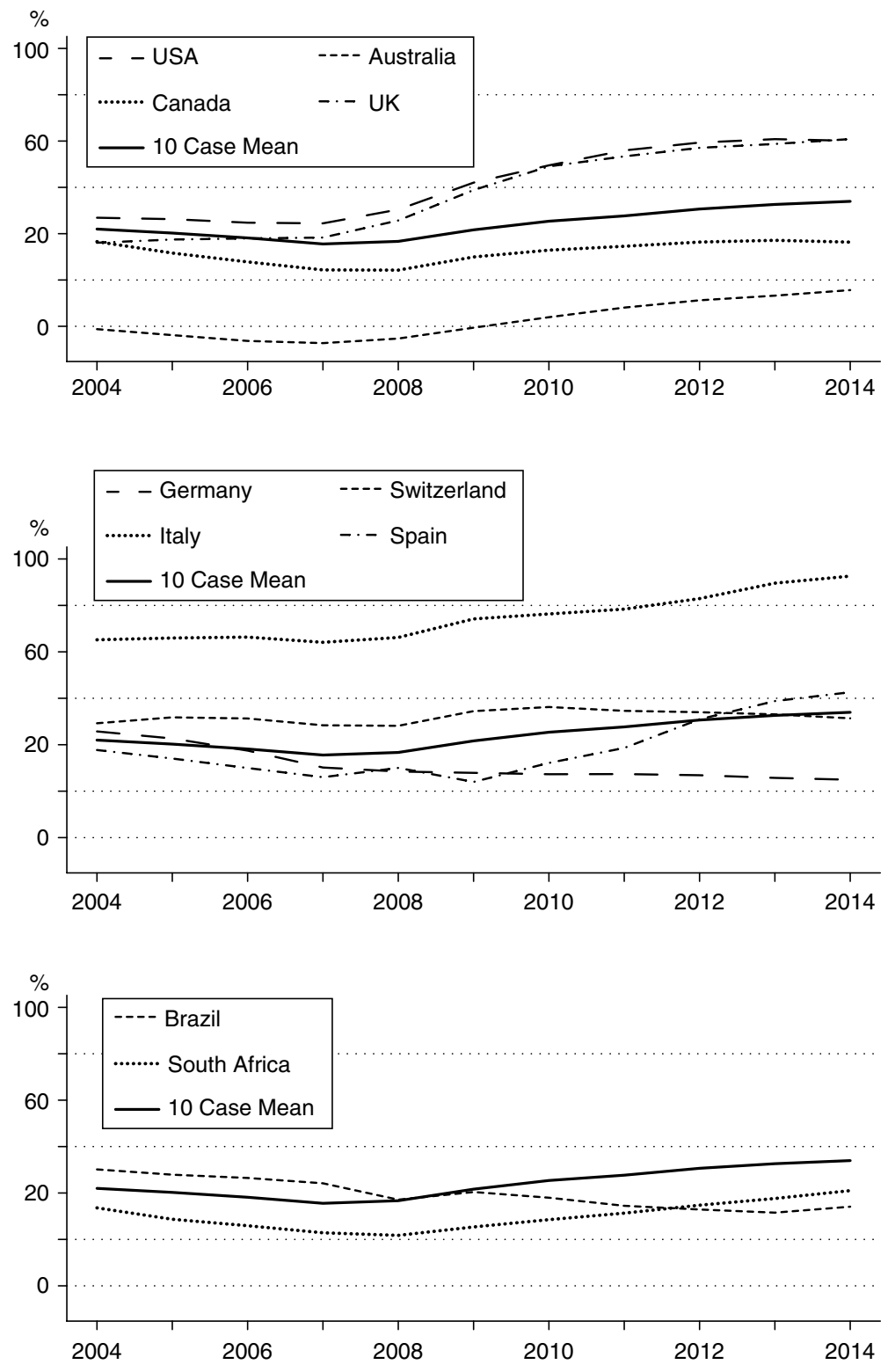

Source: OECD (2016), General government deficit (indicator).

Figure 1.4 Change in net debt (national government), 2004-14 
as Switzerland) sustained steady increases in gross domestic product (GDP), reduced general government debt and prevented unemployment from rising, while others such as Spain and Italy suffered declining GDP, spiking debt and soaring unemployment. Additionally, countries were affected in different ways depending on the nature of their economic structure and engagement with the global economy. For example, Germany and Switzerland's respective financial sectors suffered due to significant exposure to US securities (Renzsch 2010; Hänni 2010); Australia and Canada were largely insulated from the downturn by their commodity exports (Eccleston and Woolley 2014); and India experienced the crisis through reduced demand for its exported goods and services and a decrease in remittance inflows (Ghosh and Chandrasekhar 2009, pp.728-9); meanwhile Brazil suffered from the disruption of international credit markets and a consequent drop in investment (Fardoust and Ravishankar 2013, p. 18). Finally, it can also be shown that each federal state's crisis experience is shaped by its unique institutional characteristics, which play a role in determining its vulnerability to external shocks (Braun and Trein 2013, p. 345; 2014, p. 807). The theoretical basis of this argument is discussed below.

The post-2009 period has witnessed growing tensions between national and subordinate governments in many federal systems as national and subordinate governments have attempted to cope with spiralling deficits (see Figure 1.3) and mounting public debt (Figure 1.4). In the USA, some states reacted with caution to federal bailouts due to fears of increased dependency on Washington (Tarr 2010, pp.46-7). In contrast, Australian states have decried reduced national funding in key policy areas (Lynch 2014; Eccleston and Smith 2015) as the federal government has shifted to a more obdurate and confrontational position (Anderson and Parkin 2010, p. 110). Spain's traumatic experience and subsequent debt distress have contributed to Catalonia's renewed push for independence, while the crisis has also provided material for Scottish secessionists (Ordeix and Ginesta 2014, p.929). In South Africa, conflict between provinces has also emerged, with more prosperous regions questioning the fairness of equalization regimes (Steytler and Powell 2010, pp. 171-2). Germany saw its renegotiation of the federal compact disrupted by the crisis, and when discussions resumed, horizontal conflicts among länder and tensions between the national and regional governments over indebtedness and equalization intensified (Heinz 2010). These developments are unsurprising given that the usual political challenges associated with medium-term budget repair have been aggravated by the push to reduce government spending and associated fluctuations in vertical transfers to subnational governments (see Figure 1.5). Yet as the case studies that follow will testify, 

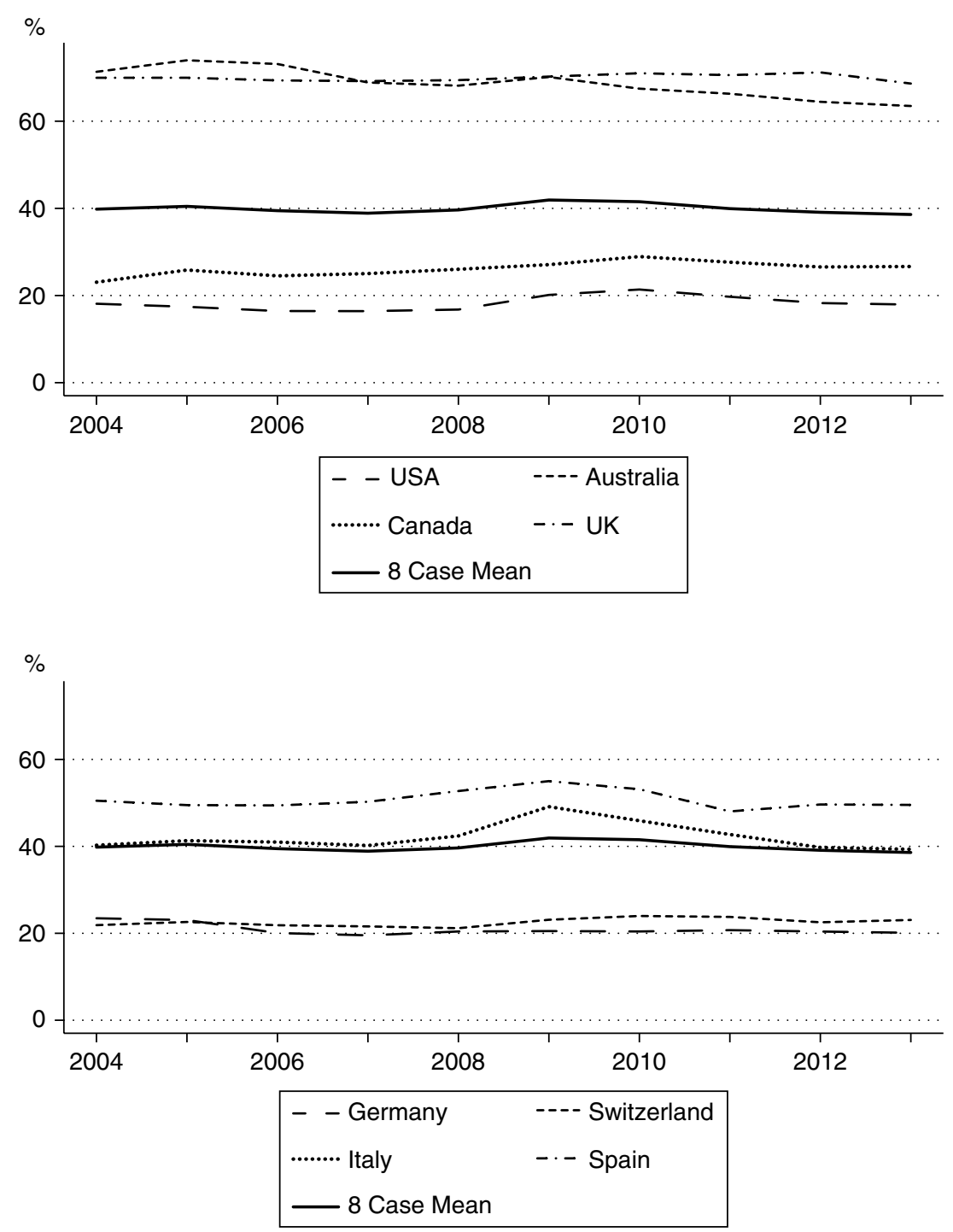

Note: Comparable data on transfers in emerging economies is not available.

Source: OECD Fiscal Decentralization Database Part D: revenue structure of state and local government.

Figure 1.5 Intergovernmental transfers, central transfers as \% of total subnational revenue - select cases, 2005-12 
there is a good deal of variation in how these fiscal pressures have impacted on patterns of intergovernmental relations.

As the preceding discussion demonstrates, there is an emerging literature focused both on how federal systems responded to the acute (first) phase of the financial crisis and some research assessing the impact of fiscal consolidation, low growth and high unemployment associated with the second phase of the crisis on the federal system. However, with but a few exceptions, there is an absence of scholarly analysis of the longerterm implications of the financial crisis and its legacies on the future of federal governance. ${ }^{4}$ One notable contribution on which this volume builds is Braun and Trein's $(2013,2014)$ set of preliminary studies of the impact of the financial crisis on patterns of fiscal policy-making. As is noted in greater detail below, Braun and Trein's contribution is significant in that it systematically engages with the extant literature on comparative federalism to develop a framework for assessing the likely short- to medium-term impact of economic crises on established federations. This approach is insightful as it explains which federations are more prone to political conflict as a result of the crisis. However, this analysis can and must be taken further if the long-term consequences of the crisis across the range of federations and contemporary intergovernmental practices are to be understood. This is the ambition for The Future of Federalism.

As noted above, Braun and Trein $(2013,2014)$ have presented the most sophisticated account to date of the medium- to long-term impact of the financial crisis on federalism. Their central contention is that the likelihood of crisis-induced change in federal systems depends on the extent of pre-existing political contestation 'vulnerability' in intergovernmental relations, combined with the intensity of the crisis and whether these two variables have precipitated political opportunism. The model intuitively anticipates that where vulnerability and financial impact are high, federal systems are likely to be subject to change in the form of either increased centralization or increased governmental opportunism and (horizontal) conflict between subnational governments leading to 'de-solidarization'.

According to Braun and Trein (2013, p. 345), Canada and South Africa feature 'system-threatening instability', with intergovernmental relations characterized by intense decentralization pressures in the former, and centralization pressures in the latter. In Spain and India the balance of power is described as being in a state of flux, with the crisis having the potential to aid central governments in an ongoing arm-wrestle with the subnational governments (Braun and Trein 2013, p. 346). Finally, Australia, Germany, Switzerland and the USA are described as having a 'stable equilibrium', with either strong subnational governments (Switzerland and the USA) or a strong central government (Germany and Australia) rendering 
significant power shifts in intergovernmental relations unlikely (Braun and Trein 2013, pp.347-8). Overall, however, Braun and Trein (2013, p. 360; 2014, p.817) conclude that despite the profound economic, social and political impact of the financial crisis on federal states, the practice of federalism since 2008 can be characterized more by continuity than change, especially in relation to the significant institutional changes that redefine federal orders.

This analytic model clearly makes a significant contribution to the nascent literature on post-crisis federal dynamics. However, more careful consideration needs to be given to the role of domestic actors in driving institutional change. It is one thing to argue that 'political opportunists' can capitalize on vulnerable, conflict-ridden federal systems, but these agents must be analysed in greater detail to explain fully who they are, the origins and nature of the interests they promote, and how they go about promoting them. To this end, theoretical accounts of change in federal systems can draw on the literature on situated agency within historical institutionalism (section 1.5).

Braun and Trein's findings in respect of variability in contemporary federal experiences stand in contrast to the historical literature on postcrisis fiscal federalism, which indicates that centralization is the standard response to an economic downturn. For example, the study by Bordo et al. (2013, p. 481) of the impact of the Great Depression found that 'central government is often strengthened in a response to exceptional events, in particular to deep economic crises'. Indeed, the context of the national security crisis and fiscal threat of the Second World War produced a profoundly significant informal change to practice in Australia, lending justification to the seizing by Canberra of the exclusive right to impose income taxes - thus ensuring the central government's financial domination of the Australian federation to this day (Eccleston 2004; Hamill 2006, pp. 96-7).

This volume will analyse these competing claims by examining the impact of the acute phase of the crisis on both the formal and informal power balances between central and subnational governments, in addition to systematically assessing the factors that have produced either centralizing or decentralizing tendencies within federations in the wake of the initial downturn. Moreover, we consider that the timing of our analysis is crucial - the findings presented in this volume suggest that the crisis cast a long shadow over federal relations and that only now, after years of tepid recovery and below-trend growth, are the political pressures for more fundamental reform coming to a head. The task of this volume is to evaluate and build on Braun and Trein's embryonic model of federal dynamics in order to enhance our understanding of the longer-term impacts of the financial crisis on the practice of federalism. 


\subsection{CRISIS, AGENCY AND A DIALECTICAL THEORY OF FEDERAL DYNAMICS}

There are strong parallels between recent accounts of federal dynamics (as outlined in section 1.4 above, with their emphasis on the interaction between actors, informal processes of adaptation and constitutional reform) and the broader literature on institutional change. As noted above, in both domains there are persistent tensions between structuralist and society-centred accounts of change. Structuralist accounts argue that, once established, constitutionally entrenched federal orders have an enduring influence over intergovernmental politics until they are displaced by a new regime with an alternative, externally defined, logic. In contrast, societal accounts of both federal and institutional change suggest that federal settlements are largely the product of changing political circumstances and preferences shaped by 'interpretive agents' reflecting prevailing norms and discourse (Lowndes 2010). Yet the empirical evidence presented in this collection and beyond suggests that the interaction between political actors and the context in which they are situated shapes and enables change.

That evidence suggests that institutional theory needs to move beyond the dichotomy of the established structure-agency debate if it is to enhance the understanding of how and why actors interact with their ever-changing institutional environment to effect political change. As Crouch (2005, p. 3) argues, the challenge is to 'devise theories of action that retain all the insights of neo-institutionalism concerning the constrained nature of human action, while also being able to account for innovation'. According to some theorists (Schmidt 2008; Bell 2011, p.886), such an agenda would make a significant contribution to institutional theory by providing much needed micro-foundations of macro-historical change. In the context of Braun and Trein's (2013) recent analysis of change in federal systems outlined in section 1.4 above, the emerging literature on 'situated agency' in historical institutionalism can provide insights into when and how domestic political actors devise and promote agendas that contribute to change in federal systems.

Particularly in the context of an analysis of the evolution of federal governance in the twenty-first century, there must be a focus on recent innovations in institutional theory that integrate agent-centred and structural theories of institutional change. Perhaps the most relevant contribution to this agenda is the 'agent-centred historical institutionalism' advocated by Stephen Bell and colleagues (Bell 2011; Marsh 2009). Drawing on precedents from across new-institutionalism (Thelen and Steinmo 1992), Bell's account suggests that institutional change is a product of intentional political action that is the product of the two-way dialectical interaction 
between agents and their institutional context in a particular historical setting (2011, p. 891). The contention is that institutional structures matter as the sources of incentives and cues that can both constrain or enable change but ultimately their impact is controlled by the actors, be they individual political leaders or policy entrepreneurs, who have discretion over the agendas and strategies that they pursue. Significantly this approach recognizes the impact of prevailing norms and ideas on patterns of institutional change, both in terms of influencing how actors interpret their political context and how they frame and legitimize calls for political action and institutional change (Hay 2004). For example, regional independence movements that are identified in the chapters which follow did not form in a political vacuum. Rather, they are a product of strategic political actors and movements exploiting changing structural economic conditions to promote and effect change to entrenched federal orders. Agents matter because ultimately the dynamics of change will be shaped by 'interpretive agents interacting dialectically with institutional and wider structural contexts' (Bell 2011, p. 884). Embracing this emerging strand of institutional theory clearly has implications for the research method and both the design and focus of the empirical analysis presented in the chapters that follow.

\subsection{RESEARCH METHOD}

If there is a consensus about the dynamic relationship between prevailing socio-economic conditions and federal orders it is that it is extremely complex, a conclusion borne out by preliminary research on the financial crisis and federalism (Kincaid et al. 2010). This reality leads to a conclusion that theory should be seen not as a basis for formal modelling or prediction, but rather as a guide for empirical analysis, providing an interpretative framework to further the understanding of processes and events (Thelen and Steinmo 1992; Hay 2002, p. 47; Kay 2006, ch. 5). Based on this understanding, the case studies contained in this volume aim to present a historically grounded account of changing federal dynamics in their respective jurisdictions. However, in order to make analytical claims across the case studies and create a theoretically informed contribution to the emerging understanding of federalism dynamics, each of the case studies will assume what Kay (2006, p.1) describes as a structured narrative, which 'seeks out the specific institutions, structures, and processes that are embodied in a given historical setting ... and will construct explanations of outcomes that link the causal properties of those structures to the processes of development that are found in the historical record'. 
A survey of relevant literature suggests that institutional change in federal orders is best understood as a consequence of multiple and historically contingent processes. Recent contributions to the literature on historical institutionalism provide a solid foundation for case studies of recent changes in fiscal federalism. Mahoney and Thelen (see Table 1.1 in section 1.3.2 above) identify specific mechanisms that may result in change, while Benz and Broschek's Federal Dynamics (2013a) provides valuable cues as to the causes of change in federal orders - including critical insights concerning the variables that will influence political vulnerability and opportunism in the aftermath of the 2008 financial crisis. As Braun and Trein (2013) rightly point out, federal dynamics are complex and occur on different levels over various time horizons. Finally, Bell (2011) has made a compelling case for a greater analytical focus on interpretative actors as the agents that ultimately instigate institutional and political change.

The interaction of factors impacting on the evolution of federalism can be conceptualized in terms of federal institutions as a mid-level variable mediating the impact of changing structural contexts and economic circumstances at a macro level on patterns of state-society relations and associated policy-making by agents at the micro level. These are complex iterative processes in which the economic consequences of the crisis will transform directly state-society and broader social relations such as developing new allocations of rights to resources, new political movements and so forth, while prompting new debates about the nature of federal settlements such as whether the current federal regime privileges one set of actors relative to others. Over time these pressures may precipitate societal change that feeds back into calls to reform federal orders. Based on the extant literature it is possible to anticipate structural and institutional characteristics that may shape subsequent federal dynamics. These features are described in Figure 1.6, which serves as a broad analytical framework for the empirical analysis that follows. However, in keeping with the ideographic method that informs this volume, this framework serves as a tool to interpret case study data rather than as a formal hypothesis that can be systematically tested.

The overall aim of this volume is to provide an informed account of the processes that are remaking federal systems in the early twenty-first century. While the broad literature on federal governance has a number of discrete theoretical traditions, increasingly the most sophisticated explanations of policy change tend to use an analytical synthesis to provide insights into federal dynamics. Methodologically this necessitates a historically grounded, inductive approach that relies on detailed empirical research but utilizes existing theoretical propositions, models and frameworks to interpret the inherent complexity of the political world. The 


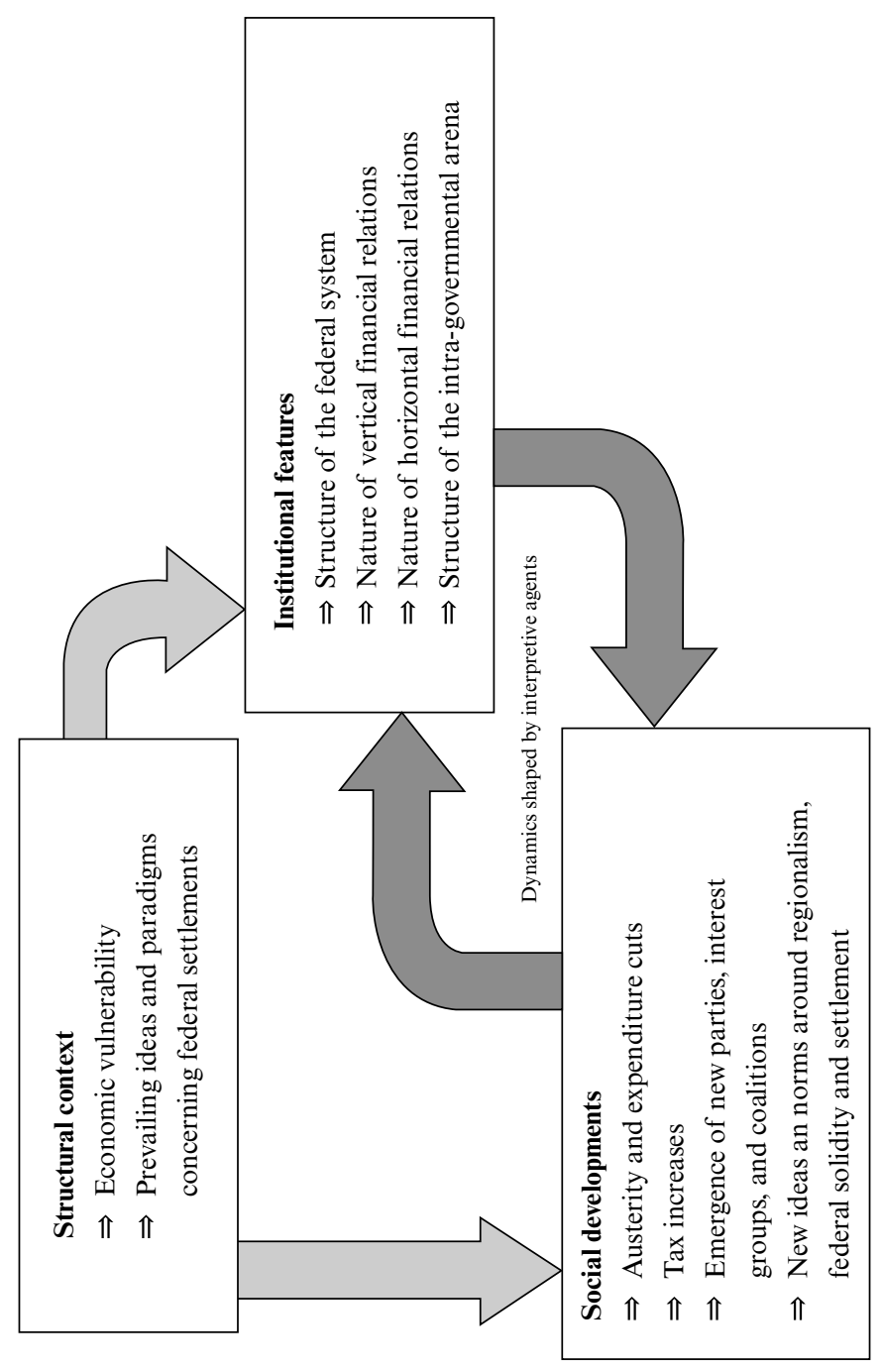

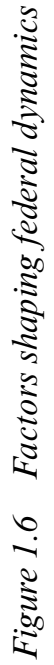


broad task of the remainder of the volume is to assess the extent to which federal dynamics across our 12 case study countries can be explained in terms of the processes described above. The case studies document the specific combinations of structural, institutional, agential and ideational factors that are contributing to change in contemporary federalism. The concluding chapter considers how this empirical evidence relates to contemporary models of policy change. The goal is to further the understanding of when and why specific modes of federal dynamics occur - a task that has been identified as being at the frontier of research on policy and institutional change.

\section{NOTES}

1. See Forum of Federations, 'Federalism in South Africa', http://www.forumfed.org/ countries/south-africa/.

2. This was perhaps most clearly articulated in Federalist Paper No. 9 (Hamilton et al. [1788], 2007).

3. Noteworthy contributions to this literature include Anderson and Fenna (2010); Hänni (2010); Kincaid (2010); Pi-Sunyer (2010); Pola (2010); Renzsch (2010); Steytler and Powell (2010); Tarr (2010); Amwe (2011) and Antic (2013). Of these contributions, only Braun and Trein $(2013 ; 2014)$ focus specifically on the impact of the 2008 financial crisis and its aftermath on federal governance.

4. Another recent contribution (albeit with a focus on the European Union) is Ahmad et al. (2016).

\section{REFERENCES}

Ackerman, Bruce (1998), We the People, Vol. 2: Transformations, Cambridge, MA: Harvard University Press.

Ahmad, Ehtisham and Giorgio Brosio (eds) (2006), Handbook of Fiscal Federalism, Cheltenham, UK and Northampton, MA: Edward Elgar.

Ahmad, Ehtisham, Massimo Bordignon and Giorgio Brosio (eds) (2016), MultiLevel Finance and the Euro Crisis: Causes and Effects, Cheltenham, UK and Northampton, MA: Edward Elgar.

Amwe, Daniel (2011), 'An evaluation of the impact of the global financial crisis on Nigerian fiscal federalism', International Research Journal of Finance and Economics, 66, 8-21.

Anderson, Geoff and Alan Fenna (2010), 'Australian federalism and the global economic crisis of 2008-09', L'Europe En Formation, 2010/4 (358), 131-48.

Anderson, Geoff and Andrew Parkin (2010), 'Federalism: a fork in the road?', in Chris Aulich and Mark Evans (eds), The Rudd Government: Australian Commonwealth Administration 2007-2010, Canberra: ANU E Press, pp. 97-118.

Anderson, George (2010), Fiscal Federalism: A Comparative Introduction, Oxford: Oxford University Press.

Antic, Dinka (2013), 'Multi-level fiscal system in Bosnia and Herzegovina: 
evolution and coping with economic crisis', Financial Theory and Practice, 37 (3), 279-310.

Banting, Keith G. (2005), 'Canada: nation-building in a federal welfare state', in Herbert Obinger, Stephan Leibfried and Francis G. Castles (eds), Federalism and the Welfare State: New World and European Experiences, Cambridge: Cambridge University Press, pp. 88-137.

Bednar, Jenna (2011), 'The political science of federalism', Annual Review of Law and Social Science, 7, 269-88.

Behnke, Nathalie and Arthur Benz (2009), 'The politics of constitutional change between reform and evolution', Publius, 39 (2), 213-40.

Beland, Daniel and John Myles (2012), 'Varieties of federalism, institutional legacies, and social policy: comparing old-age and unemployment insurance reform in Canada', International Journal of Social Welfare, 21 (Supplement), S75-S87.

Bell, Stephen (2005), 'Agents, ideas and institutional change: creative border crossing in institutionalist analysis and the case of monetary policy in Australia', mimeo.

Bell, Stephen (2011), 'Do we really need a new "constructivist institutionalism" to explain institutional change?', British Journal of Political Science, 41 (4), 883-906.

Bell, Stephen and Andrew Hindmoor (2015), Masters of the Universe, Slaves of the Market, Cambridge, MA: Harvard University Press.

Benz, Arthur and Jörg Broschek (2013a), 'Federal dynamics: Introduction', in Arthur Benz and Jörg Broschek (eds), Federal Dynamics: Continuity, Change, and the Varieties of Federalism, Oxford: Oxford University Press, pp. 1-23.

Benz, Arthur and Jörg Broschek (2013b), 'Conclusion: theorizing federal dynamics', in Arthur Benz and Jörg Broschek (eds), Federal Dynamics: Continuity, Change, and the Varieties of Federalism, Oxford: Oxford University Press, pp.366-88.

Benz, Arthur and César Colino (2011), 'Constitutional change in federations - a framework for analysis', Regional and Federal Studies, 21 (4-5), 381-406.

Beramendi, Pablo (2007), 'Federalism', in Carles Boix and Susan C. Stokes (eds), The Oxford Handbook of Comparative Politics, Oxford: Oxford University Press, pp. 752-81.

Blöchliger, Hansjörg (2013), 'Measuring decentralisation: the OECD fiscal decentralisation database', in Junghun Kim, Jorgen Lotz and Hansjörg Blöchliger (eds), Measuring Fiscal Decentralisation - Concepts and Policies, Paris: OECD Publishing.

Bordo, Michael D., Lars Jonung and Agnieszka Markiewicz (2013), 'A fiscal union for the euro: some lessons from history', CESifo Economic Studies, 59 (3), 449-88.

Braun, Dietmar and Philipp Trein (2013), 'Economic crisis and federal dynamics', in Arthur Benz and Jörg Broschek (eds), Federal Dynamics: Continuity, Change, and the Varieties of Federalism, Oxford: Oxford University Press, pp. 343-65.

Braun, Dietmar and Philipp Trein (2014), 'Federal dynamics in times of economic and financial crisis', European Journal of Political Research, 53 (4), 803-21.

Broschek, Jörg (2011), 'Conceptualizing and theorizing constitutional change in federal systems: insights from historical institutionalism', Regional and Federal Studies, 21 (4-5), 539-59.

Campbell, John (2004), Institutional Change and Globalization, Princeton: Princeton University Press. 
Canuto, Otaviano and Lili Liu (2010), 'Subnational debt finance: make it sustainable', in Otaviano Canuto and Marcelo Giugale (eds), The Day After Tomorrow: A Handbook on the Future of Economic Policy in the Developing World, Washington, DC: World Bank, pp. 219-38.

Chhibber, Pradeep K. and Ken Kollman (2004), The Formation of National Party Systems: Federalism and Party Competition in Canada, Great Britain, India, and the United States, Princeton, NJ: Princeton University Press.

Colino, César (2010), 'Understanding federal change: types of federalism and institutional evolution in the Spanish and German federal systems', in Jan Erk and Wilfried Swenden (eds), New Directions in Federalism Studies, London: Routledge, pp. 16-33.

Colino, César and Eloísa del Pino (2014), 'Spanish federalism in crisis', in Paul E. Peterson and Daniel Nadler (eds), The Global Debt Crisis: Haunting U.S. and European Federalism, Washington: Brookings Institution Press, pp. $159-78$.

Conlan, Timothy (1998), From New Federalism to Devolution: Twenty-Five Years of Intergovernmental Reform, Washington, DC: Brookings Institution Press.

Crouch, Colin (2005), Capitalist Diversity and Change, Oxford: Oxford University Press.

Dardanelli, Paolo, John Kincaid, Alan Fenna, André Kaiser, André Lecours and Ajay Kumar Singh (2015), 'Conceptualizing, measuring, and mapping dynamic de/centralization in federations', presented to the 111th Annual Meeting of the American Political Science Association, San Francisco, 3-6 September.

Eccleston, Richard (2004), The Thirty Year Problem: The Politics of Australian Tax Reform, Sydney: Australian Tax Research Foundation.

Eccleston, Richard (2007), Taxing Reforms: The Politics of the Consumption Tax in Japan, the United States, Canada and Australia, Cheltenham, UK and Northampton, MA: Edward Elgar.

Eccleston, Richard and Neil Warren (2015), 'The devil is in the detail: the distributional consequences of income tax sharing in the Australian federation', Australian Tax Forum, 30 (4), 713-33.

Eccleston, Richard and Tim Woolley (2014), 'From Calgary to Canberra: resource taxation and fiscal federalism in Canada and Australia', Publius, 45 (2), 216-43.

Eccleston, Richard and Helen Smith (2015), 'Fixing funding in the Australian Federation: issues and options for tax reform', Australian Journal of Public Administration, 74 (4), 435-47.

Elazar, Daniel J. (1987), Exploring Federalism, Tuscaloosa, AL: University of Alabama Press.

Erk, Jan (2008), Explaining Federalism: State, Society and Congruence in Austria, Belgium, Canada, Germany, and Switzerland, London: Routledge.

Erk, Jan and Edward Koning (2010), 'New Structuralism and institutional change: federalism between centralization and decentralization', Comparative Political Studies, 43 (3), 353-78.

Erk, Jan and Wilfried Swenden (2010), 'The new wave of federalism studies', in Jan Erk and Wilfried Swenden (eds), New Directions in Federalism Studies, London: Routledge and the European Consortium for Political Research, pp. 1-15.

Fardoust, Shahrokh and V.J. Ravishankar (2013), Subnational Fiscal Policy in Large Developing Countries: Some Lessons from the 2008-09 Crisis for Brazil, China and India, Washington, DC: The World Bank.

Fenna, Alan (2012), 'Adaptation and reform in Australian federalism', in Paul 
Kildea, Andrew Lynch and George Williams (eds), Tomorrow's Federation: Reforming Australian Government, Sydney: Federation Press, pp. 26-42.

Fenna, Alan (2014), 'Adaptive forces and adaptive processes in Australian federalism', paper presented to the International Political Science Association World Congress, Montreal, 19-24 July.

Filippov, Mikhail, Peter C. Ordeshook and Olga Shvetsova (2004), Designing Federalism: A Theory of Self-Sustainable Federal Institutions, Cambridge, UK: Cambridge University Press.

Galligan, Brian (2006), 'Institutions of federalism and decentralized government', in Ehtisham Ahmad and Giorgio Brosio (eds), Handbook of Fiscal Federalism, Cheltenham, UK and Northampton, MA: Edward Elgar, pp. 521-44.

Ghosh, Jayati, and C.P. Chandrasekhar (2009), 'The costs of "coupling": the global crisis and the Indian economy', Cambridge Journal of Economics, 33 (4), 725-39.

Hague, Rod and Martin Harrop (2010), Comparative Government and Politics: An Introduction, 8th edn, Basingstoke: Palgrave Macmillan.

Hall, Peter and Rosemary Taylor (1996), 'Political science and the three new institutionalisms', Political Studies, 44 (5), 936-57.

Hamill, David (2006), The Impact of the New Tax System on Australian Federalism, Sydney: Australian Tax Research Foundation.

Hamilton, Alexander, James Madison and John Jay ([1788] 2007), The Federalist Papers, Washington, DC: Filiquarian Publishing.

Hänni, Peter (2010), 'The state and the financial industry in Switzerland', L'Europe En Formation, 2010/4 (358), 111-30.

Hay, Colin (2002), Political Analysis: A Critical Introduction, Basingstoke: Palgrave Macmillan.

Hay, Colin (2004), 'Ideas, interests and institutions in the comparative political economy of great transformations', Review of International Political Economy, 11 (1), 204-26.

Heinz, Dominic (2010), 'Federal reform II in Germany', Perspectives on Federalism, $2(2), 1-14$.

Hollander, Robyn and Haig Patapan (2007), 'Pragmatic federalism: Australian federalism from Hawke to Howard', Australian Journal of Public Administration, 66 (3), 280-97.

Hueglin, Thomas and Alan Fenna (2006), Comparative Federalism: A Systematic Inquiry, Toronto: University of Toronto Press.

Hueglin, Thomas and Alan Fenna (2015), Comparative Federalism: A Systematic Inquiry, 2nd edn, Toronto: University of Toronto Press.

Kay, Adrian (2006), The Dynamics of Public Policy: Theory and Evidence, Cheltenham, UK and Northampton, MA: Edward Elgar.

Kincaid, John (1990), 'From cooperative to coercive federalism', Annals of the American Academy of Political and Social Science, 509, 139-52.

Kincaid, John, (2010), 'The global financial crisis: continuity in U.S. federalism', L'Europe En Formation, 2010/4 (358), 599-644.

Kincaid, John, G. Alan Tarr and Sonja Wälti (2010), 'Federalism and the global financial crisis: impacts and responses - introduction', L'Europe En Formation, 2010/4 (358), 3-14.

Krasner, Stephen (1984), 'Approaches to the state, alternative conceptions and historical dynamics', Comparative Politics, 26 (2), 223-45.

Livingston, William (1956), Federalism and Constitutional Change, Oxford: Clarendon Press. 
Lowndes, Vivien (2010), 'The institutional approach', in David Marsh and Gerry Stoker (eds), Theory and Methods in Political Science, 3rd edn, Basingstoke: Palgrave Macmillan, pp. 60-79.

Lynch, Andrew (2014), 'Abbott draws up new battlelines in the fight over federalism', The Conversation, 16 May, accessed 23 March 2016 at https://theconversation. com/abbott-draws-up-new-battlelines-in-the-fight-over-federalism-26743.

Mahoney, James and Kathleen Thelen (2010), 'A theory of gradual institutional change', in James Mahoney and Kathleen Thelen (eds), Explaining Institutional Change: Ambiguity, Agency, and Power, Cambridge: Cambridge University Press, pp. 1-37.

Marsh, David (2009), 'Keeping ideas in their place: in praise of thin constructivism', Australian Journal of Political Science, 44 (4), 679-96.

Oates, Wallace E. (1972), Fiscal Federalism, New York: Harcourt Brace Jovanovich.

OECD (2015), 'OECD fiscal decentralization database Part D: revenue structure of state and local government', accessed 2 August 2016 at http://www.oecd.org/ tax/federalism/oecdfiscaldecentralisationdatabase.htm.

OECD (2016), 'General government deficit (indicator)', accessed 2 August 2016 at https://data.oecd.org/gga/general-government-deficit.htm.

Oliver, Michael and Hugh Pemberton (2004), 'Learning and change in 20th century British economic policy', Governance, 17 (3), 415-41.

Ordeix, Enric and Xavier Ginesta (2014), 'Political engagement principles as the basis for new regional self-determination processes in Europe: the case of Catalonia', American Behavioral Scientist, 58 (7), 928-40.

Peters, B. Guy (1999), Institutional Theory in Political Science: The 'New Institutionalism', London: Continuum.

Peters, B. Guy and Jon Pierre (2004), 'Multi-level governance and democracy: a Faustian bargain?', in Ian Bache and Matthew Flinders (eds), Multi-Level Governance, Oxford: Oxford University Press, pp. 75-92.

Pierson, Paul (1996), 'The new politics of the welfare state', World Politics, 48 (2), 143-79.

Pierson, Paul (2000), 'Increasing returns, path dependence, and the study of politics', American Political Science Review, 94 (2), 251-68.

Pierson, Paul (2004), Politics in Time, Princeton: Princeton University Press.

Pi-Sunyer, Carles Viver (2010), 'Impact of the global economic crisis on the political decentralisation in Spain', L'Europe En Formation, 2010/4 (358), 61-90.

Pola, Giancarlo (2010), 'Italy out of the crisis: more centralized or federated?', L'Europe En Formation, 2010/4 (358), 91-109.

Polyani, Karl ([1944] 2001), The Great Transformation: The Political and Economic Origins of Our Time, Boston: Beacon Press.

Renzsch, Wolfgang (2010), 'Closing the gap? the financial crisis and the German Länder', L'Europe En Formation, 2010/4 (358), 51-60.

Riker, William H. (1964), Federalism: Origin, Operation, Significance, Boston: Little, Brown \& Co.

Rodden, Jonathan and Erik Wibbels (2010), 'Fiscal decentralization and the business cycle: an empirical study of seven federations', Economics and Politics, 22 (1), 37-67.

Rothstein, Bo (1998), 'Political institutions: an overview', in Robert E. Goodin and Hans-Dieter Klingemann (eds), A New Handbook of Political Science, Oxford: Oxford University Press, pp. 133-67.

Sawer, Geoffrey (1969), Modern Federalism, London: Watts \& Co. 
Shah, Anwar ed. (2007), The Practice of Fiscal Federalism: Comparative Perspectives, Montreal and Kingston: McGill-Queen's University Press.

Schmidt, Vivien A. (2008), 'From historical institutionalism to discursive institutionalism: explaining institutional change in political economy', paper prepared for the annual meeting of the American Political Science Association, Boston, 28 August to 1 September.

Simeon, Richard and Daniel-Patrick Conway (2001), 'Federalism and the management of conflict in multinational societies', in Alain-G. Gagnon and James Tully (eds), Multinational Democracies, Cambridge: Cambridge University Press, pp. 338-65.

Simeon, Richard and Beryl A. Radin (2010), 'Reflections on comparing federalisms: Canada and the United States', Publius, 40 (3), 357-65.

Steinmo, Sven (1993), Taxation and Democracy: Swedish, British, and American Approaches to Financing the Modern State, New Haven: Yale University Press.

Stepan, Alfred C. (1999), 'Federalism and democracy: beyond the U.S. model', Journal of Democracy, 10 (4), 19-34.

Steytler, Nico and Derek Powell (2010), 'The impact of the global financial crisis on decentralized government in South Africa', L'Europe En Formation, 2010/4 (358), 149-72.

Tarr, G. Alan (2010), 'The global financial crisis: a view from the American states', L'Europe En Formation, 2010/4 (358), 33-49.

Ter-Minassian, Teresa and Juan Pablo Jiménez (2011), Macroeconomic Challenges of Fiscal Decentralization in Latin America in the Aftermath of the Global Financial Crisis, Santiago: Economic Commission for Latin America and the Caribbean.

Tiebout, Charles M. (1956), 'A pure theory of local expenditures', Journal of Political Economy, 64 (5), 416-24.

Thelen, Kathleen and Sven Steinmo (1992), 'Historical institutionalism in comparative politics', in Sven Steinmo, Kathleen Thelen and Frank Longstreth (eds), Structuring Politics: Historical Institutionalism in Comparative Analysis, Cambridge: Cambridge University Press, pp. 1-32.

The World Bank (2015), 'World development indicators', accessed 2 August 2016 at http://wdi.worldbank.org/tables.

Treisman, Daniel (2007), The Architecture of Government: Rethinking Political Decentralization, Cambridge: Cambridge University Press.

Vartapetov, Karen (2011), 'Russian fiscal federalism under stress: federal support of regions during the global financial crisis', Eurasian Geography and Economics, 52 (4), 529-42.

Watts, Ronald L. (2008), Comparing Federal Systems, 3rd edn, Montreal and Kingston: McGill-Queen's University Press.

Wibbels, Erik (2000), 'Federalism and the politics of macroeconomic policy and performance', American Journal of Political Science, 44 (4), 687-702. 
Richard Eccleston, Richard Krever, and Helen Smith - 9781784717780 Downloaded from PubFactory at 04/26/2023 02:59:16AM via free access 